\title{
HNRNPM wt Allele
}

National Cancer Institute

\section{Source}

National Cancer Institute. HNRNPM wt Allele. NCI Thesaurus. Code C98156.

Human HNRNPM wild-type allele is located within 19p13.3-p13.2 and is approximately 44 $\mathrm{kb}$ in length. This allele, which encodes heterogeneous nuclear ribonucleoprotein $\mathrm{M}$, is involved in RNA splicing regulation. 